\title{
Groundwater Vulnerability Mapping Using Lineament Density on Standard DRASTIC Model: Case Study in Halabja Saidsadiq Basin, Kurdistan Region, Iraq
}

\author{
Twana 0. Abdullah ${ }^{1,2}$, Salahalddin S. Ali ${ }^{3}$, Nadhir A. Al-Ansari², Sven Knutsson ${ }^{2}$ \\ ${ }^{1}$ Department of Geology, University of Sulaimani, Sulaymaniyah, Iraq \\ ${ }^{2}$ Department of Civil, Environmental and Natural Resources and Engineering, Division of Mining and \\ Geotechnical Engineering, Lulea University of Technology, Sweden \\ ${ }^{3}$ University of Sulaimani, Sulaymaniyah, Iraq \\ Email: Twana.abdullah@univsul.edu.iq, salahalddin.ali@univsul.edu.iq, Nadhir.alansari@ltu.se, \\ Sven.Knutsson@ltu.se
}

Received 18 September 2015; accepted 27 October 2015; published 30 October 2015

Copyright (C) 2015 by authors and Scientific Research Publishing Inc.

This work is licensed under the Creative Commons Attribution International License (CC BY). http://creativecommons.org/licenses/by/4.0/

\section{Open Access}

\section{Abstract}

Groundwater is the most important source of water in the Halabja-Saidsadiq Basin. In this study, to generate a map of groundwater pollution vulnerability of the basin, the standard DRASTIC method has been applied. Due to the close relation between lineament density and groundwater flow and yield, the lineament density map was applied to the standard DRASTIC model in order to ensure accuracy towards the consideration of the effects of potential vulnerability to contamination. A lineament map is extracted from Enhanced Thematic Mapper plus (ETM+) satellite imagery using different techniques in remote sensing and GIS. The lineament density map illustrates that only six classes of lineament density can be identified ranged from $(0-2.4)$. The lineament density map was rated and weighted and then converted to lineament index map. This index map is an additional parameter which was added to the standard DRASTIC model so as to map the modified DRASTIC vulnerability in HSB. The standard vulnerability map, classified the basin into four vulnerability index zones: very low (34\%), low (13\%), moderate $(48 \%)$ and high $(5 \%)$. While the modified model classified the area into four categories as well: very low (28.75\%), low (14.31\%), moderate $(46.91 \%)$ and high $(10.04 \%)$. The results demonstrate that there is no significant variation in the rate of vulnerability. Therefore, the nitrate concentration between two different seasons (dry and wet) was analyzed from (30) water wells, considerable variations in nitrate concentration from dry to wet seasons had been noted. Consequently, it confirmed that the HSB are capable to receive the contaminant because of suitability in terms of geological and hydrogeological conditions. Based on this verification, it could be claimed that the effect of lineament density is 
weak on the vulnerability system in HSB, because of its low density value.

Keywords

Vulnerability, Lineament, Landsat TM 8, DRASTIC, Halabja Saidsadiq Basin (HSB)

\section{Introduction}

Many regions in the world are explicitly dependent on groundwater as one of the main water resource, specifically in the arid and semi-arid regions. In Halabja and Saidsadiq area which is located in the northeastern part of Iraq (Figure 1), groundwater plays an important role in providing water for drinking, industrial and agricultural activities. This area in the past was destructed by army attacks by chemical weapons. In addition, some parts of the area are characterized by the lack of water projects. After 2003, the area is experiencing considerable economic development and enhanced security. Furthermore, the administrative structure of Halabja has been changed from District to Governorate in March 2014; this will definitely enhance the beginning of greater economic development and advancement. In view of these changes, there is an increase in the numbers of people heading to live in this basin and its surrounding regions. This is imposing a growing demand for water which has placed substantial pressures on water resources. It should be mentioned however, that the area has large number of surface water projects which are also heavily dependent on ground water for drinking, irrigation and industry.

According to data obtained from the Directorate of Groundwater in Sulaimani City, several thousand deep wells exits in the studied area. As a consequence, the study of the groundwater resources and its potential pollution in the area become a necessity. Moreover, it is worth noting that no previous studies have been conducted on this vital area in terms of contamination.

The most suitable, effective and widely used models to assess groundwater vulnerability to a wide range of potential contaminants is DRASTIC which has been developed by Environmental Protection Agency (EPA) of the United States to organize the pollution potential of aquifers [1]-[7].

In any specified area, vulnerability to contamination identifies a dimensionless index function of hydrogeological factors, anthropogenic influences and sources of contamination [8]. The DRASTIC index comprises seven parameters with different rating and weighting value and is calculated based on the following equation [1]:

$$
\mathrm{V}=\sum_{i=1}^{7}(\mathrm{Wi} \times \mathrm{Ri})
$$

where: $\mathrm{V}=$ index value, $\mathrm{Wi}$ = weighting coefficient for parameter $\mathrm{i}$ and $\mathrm{Ri}=$ related rating value.

DRASTIC method as designed by [1] consist of seven physical parameters. The most important mapable factor that control groundwater pollution is the Depth to groundwater (D), Net recharge (R), Aquifer media (A), Soil media (S), Topography (T), Impact of vadose zone media (I), and Hydraulic conductivity (C). These parameters are weighted from one to five based on their relative significance in contributing to the contamination potential. All rating and weighting value are explained in Table 1 based on [1]. The achieving index is a qualified measure of vulnerability to contamination; areas with a higher index value are more vulnerable than those with a lower index.

The objective of this study is to prepare the lineament density map of HSB and employ it as an additional parameter to the DRASTIC model to exemplify the realistic potential of groundwater vulnerability to pollution The lineaments refer to as linear features perceived on satellite images, aerial photographs and Digital elevation model (DEM) after processing and enhancing, which most probably related or originated from a geological feature. In addition, based on the previous studies, a close relationship has been recognized between lineaments or lineaments density and groundwater flow and yield [9]-[11]. Consequently, mapping of lineaments is crucial to groundwater survey, management and development [12]. Higher values of lineament density might designate more potential groundwater contamination. A lineaments map is extracted from Enhanced Thematic Mapper plus (ETM+) satellite imagery using different techniques in remote sensing and GIS environment. 
Table 1. Data for the DRASTIC index [1].

\begin{tabular}{|c|c|c|c|c|c|c|c|c|c|c|c|c|c|}
\hline \multicolumn{2}{|c|}{ Depth to Water } & \multicolumn{2}{|c|}{ Net Recharge } & \multicolumn{2}{|c|}{ Aquifer Media } & \multicolumn{2}{|c|}{ Soil Media } & \multicolumn{2}{|c|}{ Topography } & \multicolumn{2}{|c|}{$\begin{array}{c}\text { Impact of } \\
\text { Vadose Zone }\end{array}$} & \multicolumn{2}{|c|}{$\begin{array}{l}\text { Hydraulic } \\
\text { Conductivity }\end{array}$} \\
\hline Range (m) & Rating & $\begin{array}{c}\text { Range } \\
\text { (mm/year) }\end{array}$ & Rating & Range & Rating & Range & Rating & Range \% & Rating & Range & Rating & $\begin{array}{l}\text { Range } \\
\text { (m/day) }\end{array}$ & Rating \\
\hline $0-4.5$ & 10 & $<50$ & 1 & Massive Shale & 2 & $\begin{array}{l}\text { Thin or } \\
\text { Absent, } \\
\text { Gravel }\end{array}$ & 10 & $0-2$ & 10 & $\begin{array}{l}\text { Confining } \\
\text { Layer }\end{array}$ & 1 & $<4$ & 1 \\
\hline $1.5-4.5$ & 9 & $50-100$ & 3 & $\begin{array}{l}\text { Metamorphic/ } \\
\text { Igneous }\end{array}$ & 3 & Sand & 9 & $2-6$ & 9 & Silty/Clay & 3 & $4-12$ & 2 \\
\hline $4.5-7.5$ & 8 & $100-175$ & 6 & $\begin{array}{l}\text { Weathered } \\
\text { Metamorphic/ } \\
\text { Igneous }\end{array}$ & / & Peat & 8 & $6-12$ & 5 & Shale & 3 & $12-30$ & 4 \\
\hline $10-12.5$ & 6 & $>250$ & 9 & $\begin{array}{l}\text { Bedded } \\
\text { Sandstone, } \\
\text { Limestone, } \\
\text { Shale }\end{array}$ & 6 & Sandy Loam & 6 & $>18$ & 1 & $\begin{array}{l}\text { Sandston, } \\
\text { Beded } \\
\text { Limeston }\end{array}$ & 6 & $40-80$ & 8 \\
\hline $12.5-15$ & 5 & & & $\begin{array}{l}\text { Massive } \\
\text { Sandstone, } \\
\text { Massive } \\
\text { Limestone }\end{array}$ & 6 & Loam & 5 & & & $\begin{array}{l}\text { Sandstone, } \\
\text { Shale, sand } \\
\text { and Gravel }\end{array}$ & 6 & $>80$ & 10 \\
\hline $15-19$ & 4 & & & $\begin{array}{l}\text { Sand and } \\
\text { Gravel }\end{array}$ & 8 & Silty Loam & 4 & & & $\begin{array}{l}\text { Metamorphic/ } \\
\text { Igneous }\end{array}$ & 4 & & \\
\hline $19-23$ & 3 & & & Basalt & 9 & Clay Loam & 3 & & & $\begin{array}{l}\text { Sand and } \\
\text { Gravel }\end{array}$ & 8 & & \\
\hline $23-30$ & 2 & & & $\begin{array}{c}\text { Karst } \\
\text { Limestone }\end{array}$ & 10 & Muck & 2 & & & Basalt & 9 & & \\
\hline$>30$ & 1 & & & & & $\begin{array}{c}\text { Non } \\
\text { Shrinking } \\
\text { and Non- } \\
\text { Aggregated } \\
\text { Clay }\end{array}$ & 1 & & & $\begin{array}{c}\text { Karst } \\
\text { Limestone }\end{array}$ & 10 & & \\
\hline $\begin{array}{l}\text { DRASTI } \\
\text { Weight: }\end{array}$ & & $\begin{array}{l}\text { DRAST } \\
\text { Weight }\end{array}$ & & $\begin{array}{l}\text { DRASTI } \\
\text { Weight: }\end{array}$ & & $\begin{array}{l}\text { DRAST } \\
\text { Weight }\end{array}$ & & $\begin{array}{l}\text { DRAS } \\
\text { Weigh }\end{array}$ & $\begin{array}{l}\mathrm{IC} \\
1\end{array}$ & $\begin{array}{l}\text { DRASTI } \\
\text { Weight: }\end{array}$ & & $\begin{array}{l}\text { DRAS } \\
\text { Weigl }\end{array}$ & $\begin{array}{l}\text { IC } \\
3\end{array}$ \\
\hline
\end{tabular}

\section{Study Area}

Geographically, Halabja Saidsadiq Basin is located in the northeastern part of Iraq between the latitude 3860000 and $3930000 \mathrm{~N}$ and the longitude 560000 and $610000 \mathrm{E}$ (Figure 1). Ali [13] had divided this basin into two sub-basins including Halabja-Khurmal and Said Sadiq sub-basins. The whole area of both sub-basins is about 1278 square kilometers with population of about 190,727 in early 2015 according to the data achieved from Statistical Directorate in Sulaimaniyah. It is characterized by a distinct continental interior climate with hot summers and cold winters of the Mediterranean type with the average annual precipitation ranging from 500 to 700 $\mathrm{mm}$. About $57 \%$ of the studied area is an arable area due to its suitability for agriculture. Consequently, the use of fertilizers and pesticides are common practices, so it affects the groundwater quality [14]. In addition, all of the municipal wastewater from the cities of Halabja and Saidsadiq and all other sub-district sites within this basin infiltrate into the groundwater every year. 


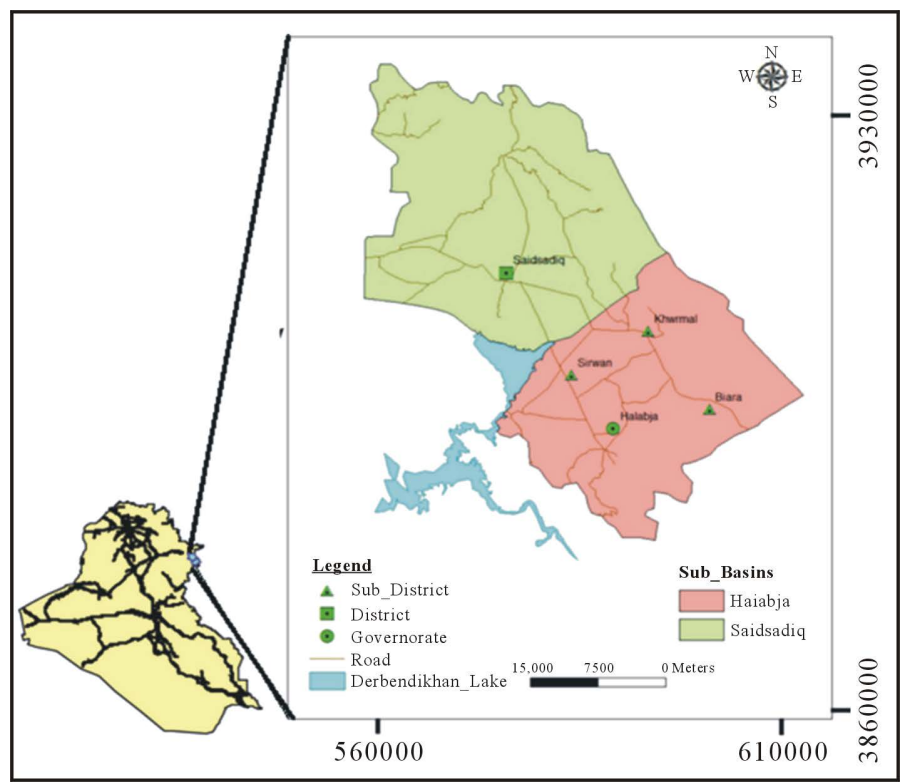

Figure 1. Location map of HSB.

\subsection{Geology of Study Area}

Geologically, the studied area is located within Western Zagros Fold-Thrust Belt. Structurally, located within the High Folded zone, Imbricated, and Thrust Zones [15]-[17]. The age of the exposed rocks in the area is from Jurassic to recent (Figure 2, Figure 3). The oldest exposed rocks in the basin are of Sarki and Sehkanian of Jurassic age [18]. These are followed by lower and middle Jurassic rocks including Barsarin (limestone and dolomitic limestone), Naokelekan (bituminous limestone) and Sargalu Formations, [13]. The Qulqula Group consists of two formations, the Qulqula Radiolarian Formation and the Qulqula Conglomerate Formation. Furthermore, the exposures of the Upper Cretaceous Kometan (Turonian) and Lower Cretaceous Balambo (Valanginian-Cenomanian) Formations are widespread in the area where they are exposed in both sub-basins. Shiranish Formation (Campanian) and Tanjero Formation (Campanian-Maastrichtian) are also exposed in the basin but with restricted outcrops.

Quaternary (Alluvial) deposits are the most important unit in the area in terms of hydrogeological characteristic and water supply. These sediments are deposited as debris flow on the gently sloping plains or as channel deposits or as channel margin deposits and over bank deposits [13]. Previous studies such as [13] [19] [20] stated that the thickness of these deposits are recorded up to $150 \mathrm{~m}$ thick while field observations in this study has recorded thicknesses of these deposits up to nearly $300 \mathrm{~m}$.

\subsection{Hydrogeology of Study Area}

Permeability and porosity are the main principal factors in determining the potential of the area to be considered as a water bearing aquifer. The area is characterized by at least four different hydrogeological aquifers due to presence of different geological units. The characteristic features of the aquifers are tabulated in Table 2. From the collected data in the field and those listed in the archives of the Groundwater Dirctorate at Sulaimaniyah show that the mountain series, which surround the basin in the northeast and southeast, are characterized by high depth of groundwater. Toward the center and the southeastern part, the groundwater level has a relatively lower depth. The movement of groundwater is usually from high elevated areas at the north and northeast and south and southeast towards southwest or generally toward the reservoir of Derbandikhan Dam (Figure 4).

Furthermore, several rivers exist in the area, such as Sirwan, Zalm, Chaqan, Biara, Reshen and Zmkan. All these rivers impound their water in Derbandikhan reservoir. There are several springs within the basin. These springs can be classified into three classes according to their water discharge. The first group having discharge that is less than $10 \mathrm{~L} / \mathrm{S}$ (such as Anab, Basak, Bawakochak and 30 other springs springs). The second group having discharge of 10 to100 L/S (such as Sheramar, Qwmash, Khwrmal and Kani Saraw) and finally those 


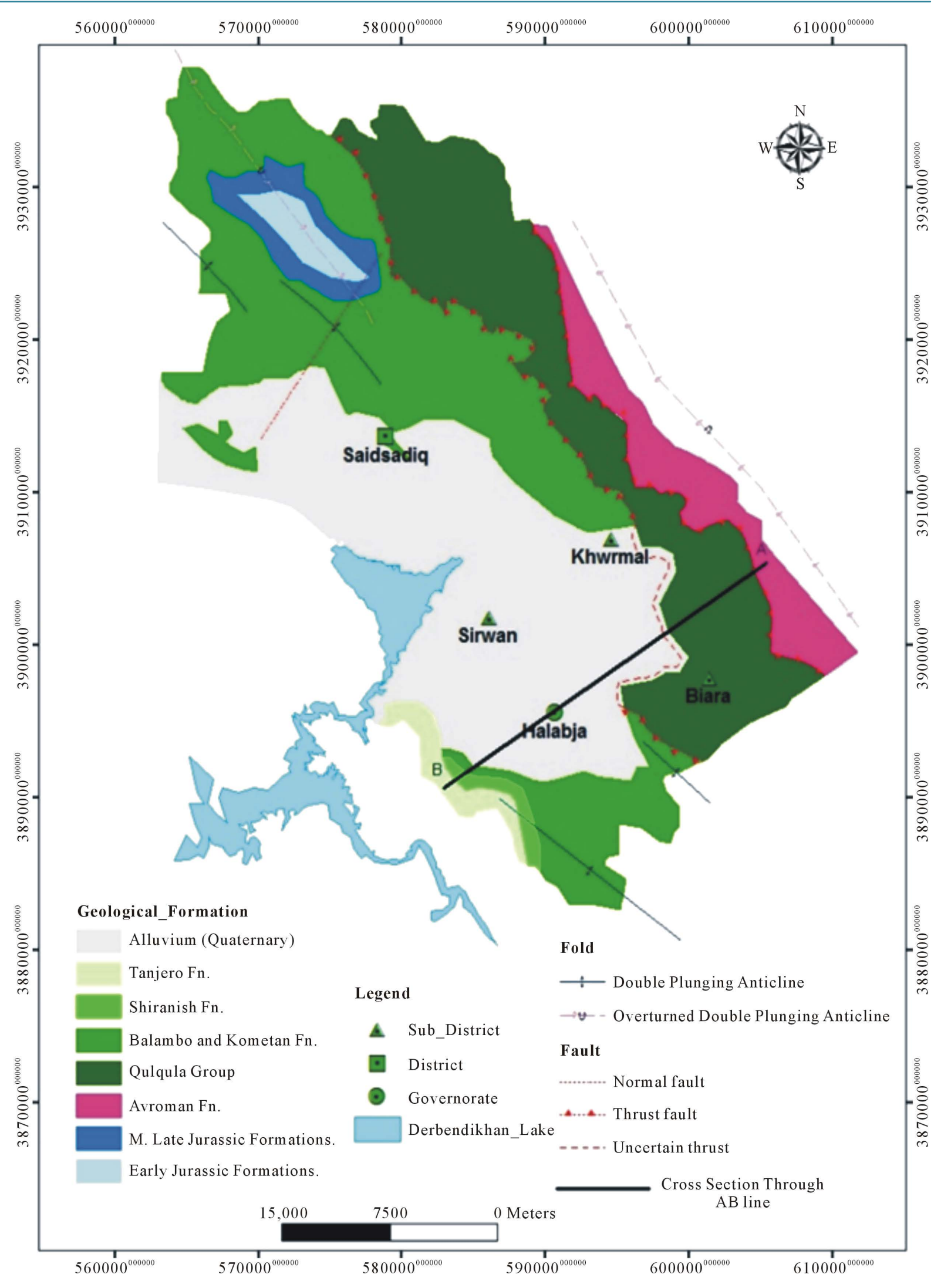

Figure 2. Geological map of HSB. 


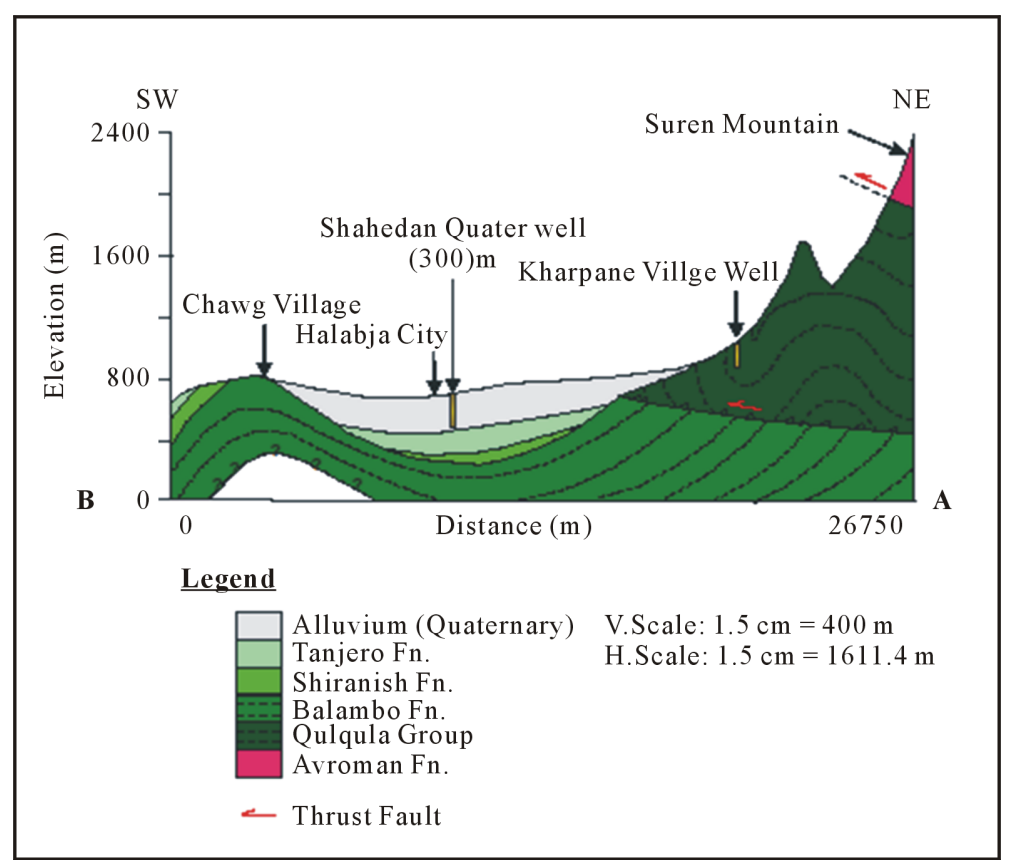

Figure 3. Cross section through line A-B [13] [21].

Table 2. Types of aquifers in the study basin.

\begin{tabular}{cccc}
\hline Aquifer Type & Geological Formation & Thickness (m) & References \\
\hline Intergranular Aquifer & Quaternary deposits & More than 300 & \\
Fissured Aquifer & Balambo & 250 \\
Kometan & Authors & 200 \\
Fissured-Karstic Aquifer & Avroman & From 80 to 200 \\
& Jurassic Formation & More than 500 & Jassim and Goff, 2006 \\
Non-Aquifer (Aquitard) & Qulqula & 225 & Jassim and Goff, 2006 \\
& Shiranish & 2000 & \\
\hline
\end{tabular}

having water discharge more than 100 L/S (such as Garaw, Ganjan, Reshen, Sarawy Swbhan Agha and 3 other springs) (Figure 4). The regional lineaments in HSB have been showed on Figure 4 [22].

\section{Methodology}

\subsection{Material and Source of Data}

The data used and their source for groundwater vulnerability mapping are presented in Table 3 . Features were used to create the shape files with (Arc Map 10) software, including the geological, hydrogeological, soil map and hydrochemical data for the study area. The topographic map of the area was digitized and converted from slope map into shape files. Depth to water levels was measured from several wells in the field using electrical sounder in addition to previous records of drilled and tested wells. The thickness of saturated zone was determined from drilled wells directly supervised by researchers for this study during field work. In addition, relevant data were added which were obtained from the Groundwater Directorate in Sulaimani [23] and other private companies. Pumping test results of the wells within the area were used to calculate the hydraulic conductivity. "AQTESOLV" software was used in these calculations. Lineament map and lineament density map were prepared using satellite image remote sensing technique with the aid of (Envi Program and PCI Geomatica technique) and GIS. The modified DRASTIC model prepared from standard one and lineament density map applied in GIS environment. 


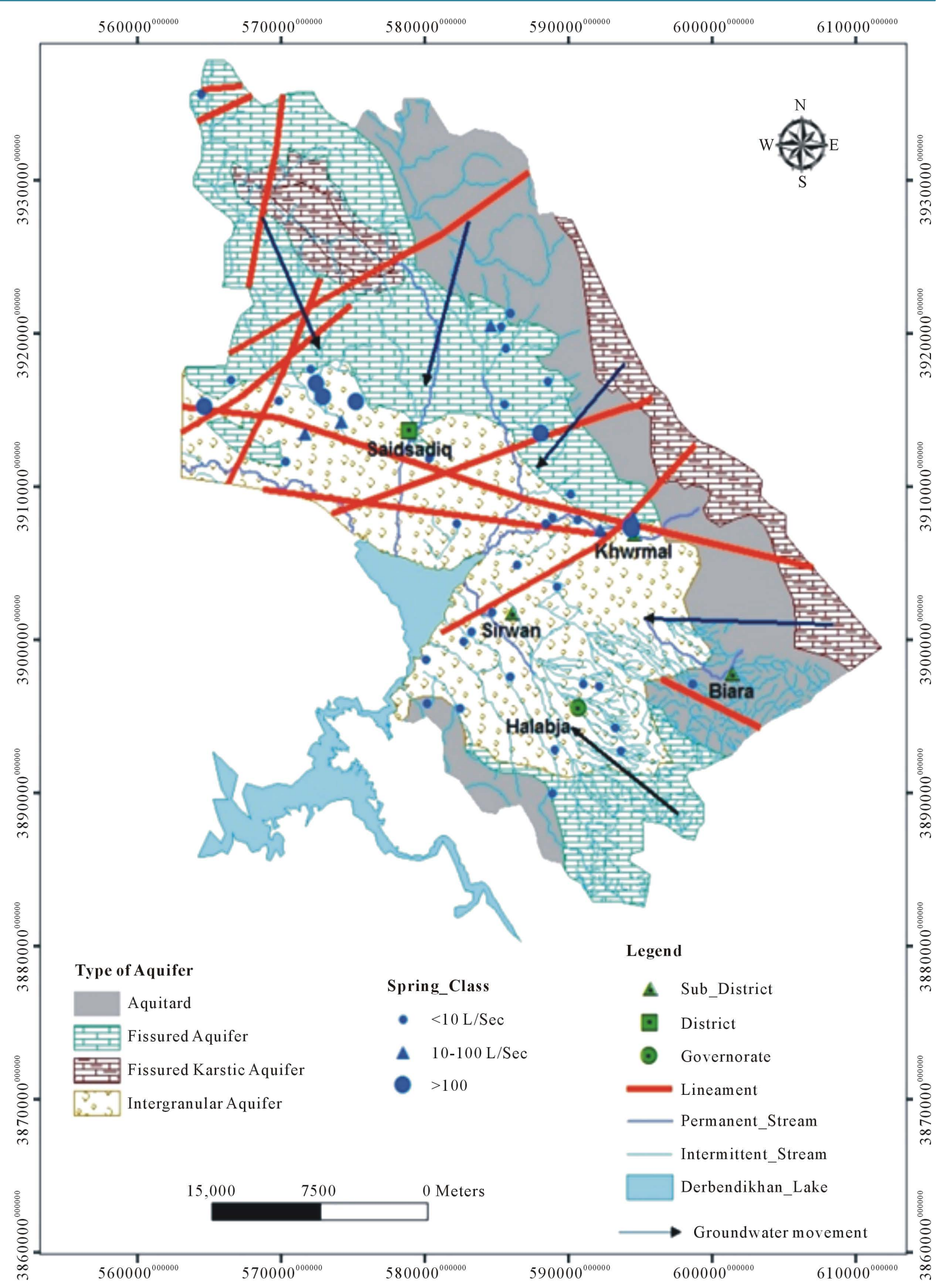

Figure 4. Hydrogeological map of HSB. 
Table 3. Source of data for DRASTIC model and Lineament map.

\begin{tabular}{cc}
\hline Data Type & Sources \\
\hline $\begin{array}{c}\text { Depth to Water Table } \\
\text { Net Recharge } \\
\text { Aquifer Media } \\
\text { Soil Media }\end{array}$ & Achieves of Groundwater Directorate in Sulaimani with Data from Field. \\
Hopographic Map & Solabja Meteorological Station and Water Balance Method. \\
Impact of Vadose Zone & DEM with 30 m Pixel Size. \\
Hydraulic Conductivity & Achieves of Groundwater Directorate in Sulaimani with Data From Field. \\
Lineament Map & From Landsat 8 Date Back to (11/2/2013). \\
\hline
\end{tabular}

\subsection{Standard DRASTIC Model}

DRASTIC model applied in a GIS environment has been used to evaluate the vulnerability of the study area. This model is recommended by the United State committee of Environmental Protection Agency [1]. Seven parameters are used in the model (see Table 2) to represent the concept of the hydrogeological setting that includes the major geologic and hydrologic factors affecting and controlling the groundwater movement into, through and out of an area [1]. Each parameter has a specific rate and weight value in order so that the intrinsic vulnerability index van be evaluated. In addition, [1] defined the seven parameters by the short form "DRASTIC" which is used to mapping groundwater Vulnerability (Table 1). Each parameter has a rating on a scale of 1 to 10 , based on functional curves. This rating is then scaled by a weighting factor from 1 to 5 ; according to their relative susceptibility to pollutants. The standard DRASTIC index (DI(w-r)) calculated is based on the linear combination of all parameters as demonstrated by the following equation:

$$
\mathrm{DI}=\mathrm{DWDr}+\mathrm{RWRr}+\mathrm{AWAr}+\mathrm{SWSr}+\mathrm{TWTr}+\mathrm{IWIr}+\mathrm{CWCr}
$$

where: DI is the DRASTIC Index, (D, R, A, S, T, I and C) are the seven parameters, $w$ is the weight parameter and $\mathrm{r}$ is the rate of the parameter. All the recommended rate and weight are scheduled in Table 1.

$\mathrm{D}$ is the depth to groundwater which is describes as the distance of unsaturated zone that pollutant desires to travel through to reach the water table. For this paper, groundwater level were measured and documented in about 1200 wells. Water table measurements were taken in May and early June because these months are considered as the potential worst-case scenario due to the low depth of groundwater. The Inverse Distance Weighted (IDW) were used to interpolate the data to construct the depth to water table layer as a raster format and then reclassified based on the ranges and rating recommended by [1]. In Halabja-Saidsadiq basin the depth to groundwater vary from zero to more than $100 \mathrm{~m}$. Therefore, ten classes were used for the studied basin. These are 0 - 1.5, 1.5 - 4.5, 4.5 - 7.5, 7.5 - 10, 10 - 12.5, 12.5 - 15, 15 - 23, 23 - 30 and more than $30 \mathrm{~m}$.

$\mathrm{R}$ is the net recharge which defines the amount of water that penetrates into ground and move through the unsaturated zone to reach the water table. The net recharge was estimated from the meteorological data for the period starting from 2001-2002 to 2013-2014 based on the following equation which was recommended by [24]:

$$
\mathrm{NR}=\mathrm{P}-\mathrm{ET}-\mathrm{R} 0
$$

where, NR: is the net recharge in $\mathrm{mm} / \mathrm{year}, \mathrm{P}$ : is the annual precipitation in $\mathrm{mm}$; ET is the calculated evapotranspiration in $\mathrm{mm} /$ year, $\mathrm{R} 0$ is the total runoff in $\mathrm{mm}$. $\mathrm{P}$ was calculated from the average total yearly precipitation which is about (691.16) $\mathrm{mm} /$ year. While ET were calculated based on Crop Water Balance method by FAO Penman Monteith method using (CROPWat8.0) software [25]. R0 was calculated based on Soil Conservation Service method (SCS) to estimate the total runoff for the basin. The basin was divided into several curve number (CN) that was recommended by [1] and then using the following equation:

$$
\mathrm{Q}=(\mathrm{P}-0.2 \mathrm{~S}) 2 /(\mathrm{P}+0.8 \mathrm{~S}) \text { for } \mathrm{P}>0.2 \mathrm{~S}
$$




$$
\mathrm{S}=(25,400 / \mathrm{CN})-254
$$

where: $\mathrm{Q}=$ accumulated runoff excess in (mm). $\mathrm{P}=$ accumulated average monthly rainfall (mm). So the annual runoff of this basin is about $169 \mathrm{~mm}$ and the annual net recharge for whole basin is equal to $172.54 \mathrm{~mm}$. Finally, the net recharge map of the basin constructed was based on the net recharge percent distribution over the basin and then the resulted map was converted from polygon to raster format in GIS environment.

Aquifer media (A) and the impact of vadose zone were constructed based on the geological map of the basin and from the drilling well logs. Four sections of the aquifer media were classified in the studied basin. The rated value for each media based on [1] was illustrated as $(9,6,5$ and 3). While three segment of vadose zone were comprised with organized rating value of 4,5 and 8 . S is the soil media (texture and type) which defines the ability of a pollutant to move vertically into the vadose zone [26]. Three different soil media were found in the area based on soil map proposed by [21] [27] including, Silty loam, Shrinking and/or aggregated clay and thin or absent with rating of 4,7 and 10 respectively.

$\mathrm{T}$ map refers to the topographic map that describes the slope of the surface area. The pollutants are remaining for a long period over an area with low percent of slope value and vice versa [28]. This map was constructed from the digital elevation model (DEM) with pixel size of $(30 \mathrm{~m})$ and the slope aspect was then calculated from it in Arc GIS 10. The topography of the area was classified into five classes ranging as $0 \%-2 \%, 2 \%-6 \%, 6 \%$ $12 \%, 12 \%-18 \%$ and more than $18 \%$. Hydraulic conductivity (C) describes the ability of the aquifer material to transmit water through it and contaminant migration is control by the permeability of the media [29]. The hydraulic conductivity map was constructed by employing the pumping test result of about 100 wells. The pumping test data were analyzed using (AQTESOL 4.0) software to determine the transmissivity of the aquifer and then Equation (6) was used to calculate the hydraulic conductivity:

$$
\mathrm{C}=\mathrm{T} / \mathrm{b}
$$

where: $\mathrm{C}$ is the hydraulic conductivity in (m/day), $\mathrm{T}$ is the transmissivity in $\left(\mathrm{m}^{2} /\right.$ day) and $\mathrm{b}$ is the aquifer saturated thickness in (m). The area with high hydraulic conductivity revealed higher chance of distributing pollutants. Two classes of conductivity rating were achieved 1 and). After generating all the required layers, each pixel was classified and rated, then, multiplied by their respective weighting factor and the DRASTIC index was determined. The final index obtained was divided into several groups as proposed by [1]. Small value designated low vulnerability potential while large value represents areas that have high vulnerability potential.

\subsection{Lineament Map and Lineament Density Map}

The lineament defines as linear features in a landscape identified on satellite images and aerial photographs, most likely have a geological origin. Generally, lineaments are underlain by structural zone, fractured zone, a series of fault or fold-aligned hills zone of localized weathering and zone of increased permeability and porosity.

Lineament distribution for HSB prepared using image of landsat 8 Thematic Mapper (TM). Images consist of nine spectral bands with cell size $(30 \times 30 \mathrm{~m})$. The Operational Land Imager (OLI) spectral band in gray scale was used. Nearly, scene size is $170 \mathrm{~km}$ north-south by $183 \mathrm{~km}$ east-west and the date back to (11-02-2013). Figure 5 illustrate the TM landsat image for the study basin with extracted lineament distribution.

A lineament distribution over the site extracted using PCI Geomatica technique. The lineament extraction algorithm of PCI Geomatica software consists of edge detection, thresholding and curve extraction steps [30]. Figure 6 illustrates the final lineament distribution over HSB extracted from mentioned above satellite image.

Furthermore, the lineament density map was constructed using line density in the spatial analysis tool in Arc Map 10. This tool calculates a magnitude per unit area from polyline features that fall within a radius around each cell. Higher intensity of lineament feature may increases the probability of contaminant movement toward groundwater.

\subsection{Lineament Rating and Index Map}

In HSB area most of aquifers that surrounding the basin are developed in fractured rock, so groundwater mostly moves through the fracture of the rocks. In addition there are many linear features that appear in the alluvial deposits as a result of effective of zone of increasing porosity and permeability. So, lineament density measured as a main parameter with DRASTIC model to assess groundwater vulnerability more precisely. The lineament 
T. O. Abdullah et al.

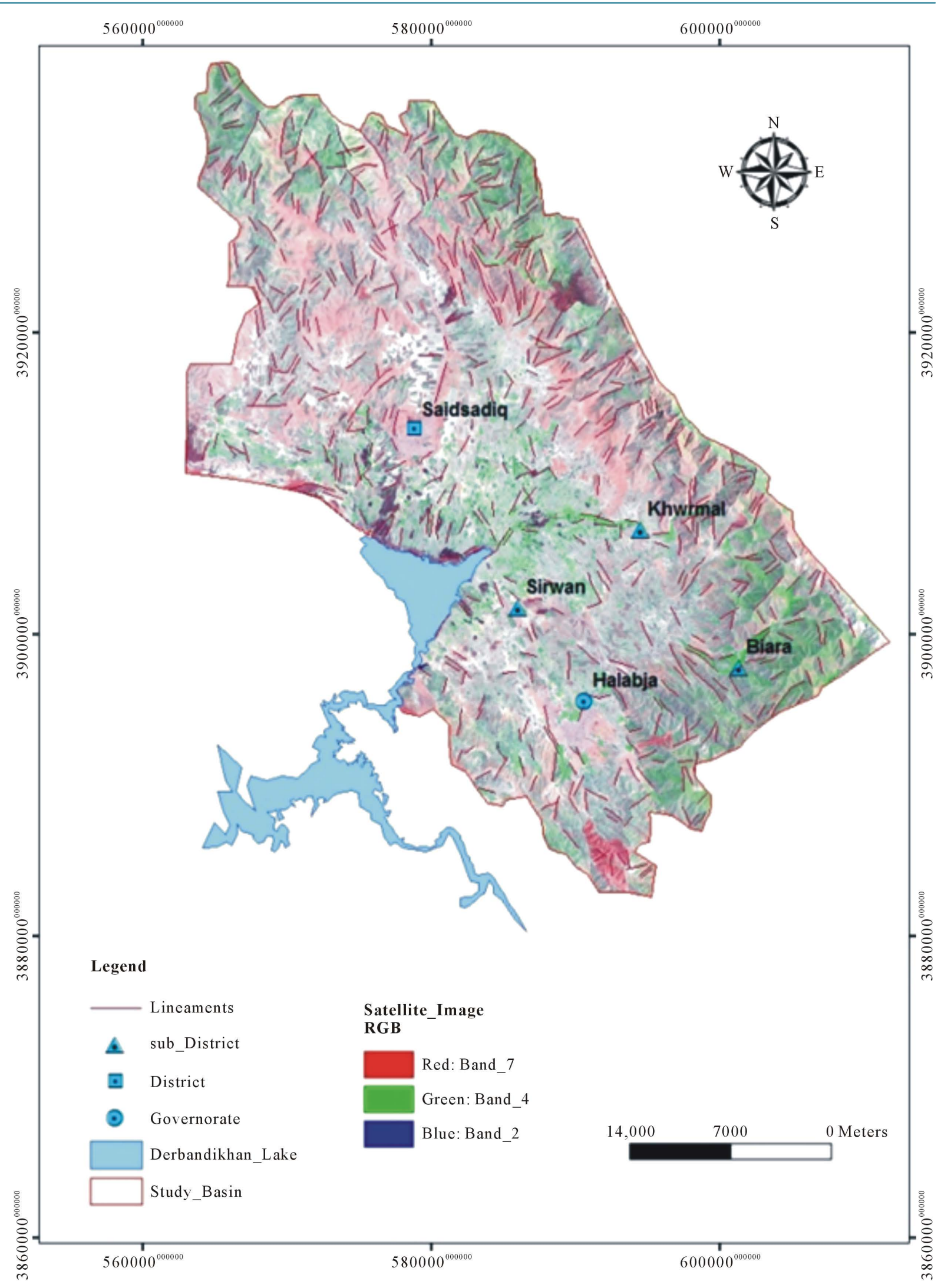

Figure 5. TM landsat 8 image (2013) of HSB. 


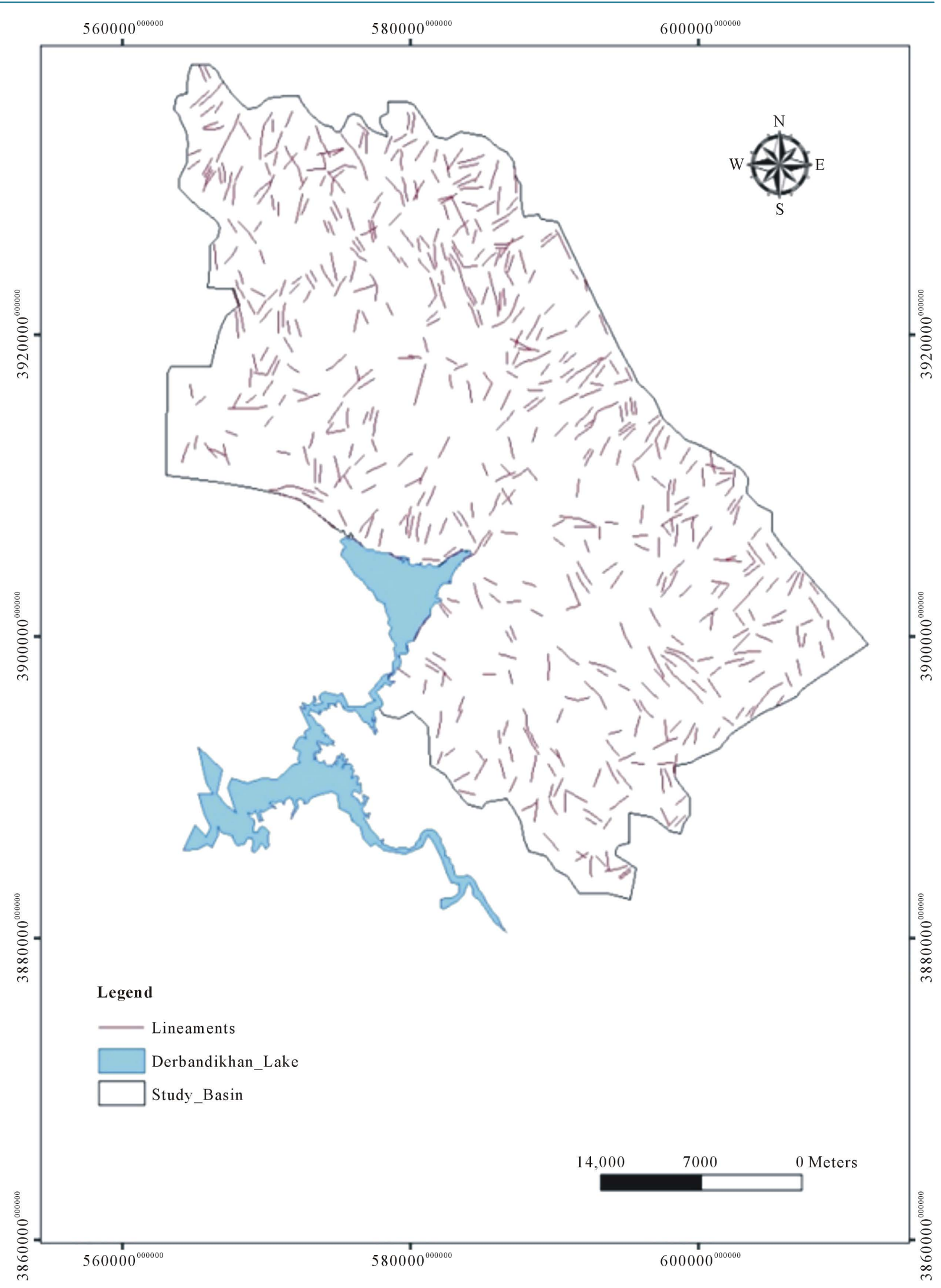

Figure 6. Extracted lineament map of HSB with extracted lineament. 
density map as showed in Figure 8 had been rated and weighted. The calculated lineament density was assigned ranges and rating based on Table 4. The weight of lineament density was assigned a value based on its valuable significance and it measured as (5), [9] [31]. Therefore, lineament index map constructed by multiplying the mentioned weigh to the rated lineament map using map algebra tool in Arc map 10 software.

\subsection{Modify Standard DRASTIC Model Using Lineament Index Map}

To modify likely risk of groundwater vulnerability an additional parameter can be added into the original DRASTIC model to show the realistic of vulnerability assessment. In this study, Lineament map is used because of its close relationship with groundwater. In addition, previous studies revealed that there is a close relation between lineament and groundwater yield and flow [10]. Therefore, Lineament index map as additional parameter added to standard DRASTIC model based on the Equation (7) [9]. The result demonstrates the effect of lineament concentration on the vulnerability system.

$$
\mathrm{DL}(\mathrm{i})=\mathrm{DI}+(\text { Lineament density Index })
$$

where: MD(i) is the modified DRASTIC model based on density of lineament; DI is the standard DRASTIC index and the Lineament density index (ratings·weights).

\section{Result and Discussion}

\subsection{Assessment of Standard Vulnerability Mapping}

Figure 7 show the standard DRASTIC vulnerability model of HSB with four vulnerability classes including: very low, low, moderate and high vulnerability index. The map obviously illustrates the dominance of moderate and very low vulnerability zones which covers an area of 614 and $435 \mathrm{Km}^{2}$ or (48\% and 34\%) of the whole studied area respectively. In terms of the geological and hydrogeological conditions, moderate vulnerability zone occupies two different areas. The first one is the mountains surrounding the studied basin that includes the fissured and karstic aquifer. While the second area comprises the Quaternary deposits surrounding the area of Derbandikhan reservoir in the southwest of the basin, this might be related to the high water table level and high percent of coarse grain material such as gravel, sand and rock fragment. Furthermore, the zone with low vulnerability considers as the third class in terms of spreading and occupy $166 \mathrm{~km}^{2}$ or $13 \%$ of the overall surface area of the basin. The zone with high vulnerability index cover only $64 \mathrm{~km}^{2}$ or $5 \%$ of the total area and is located in the center of basin. This area is characterized by high water table level and presence of several springs with fractured limestone.

\begin{tabular}{|cc|}
\hline Table 4. Rate and weight for Lineament density [9]. \\
\hline Range of Lineament Density & Rate \\
\hline $0.2-1.1$ & 1 \\
$1.2-1.3$ & 2 \\
$1.4-1.5$ & 3 \\
$1.5-1.8$ & 4 \\
$1.9-2.0$ & 5 \\
$2.1-2.2$ & 6 \\
$2.3-2.4$ & 7 \\
$2.5-2.6$ & 8 \\
$2.7-2.8$ & 9 \\
$2.9-4.0$ & 10 \\
& Weight = 5
\end{tabular}




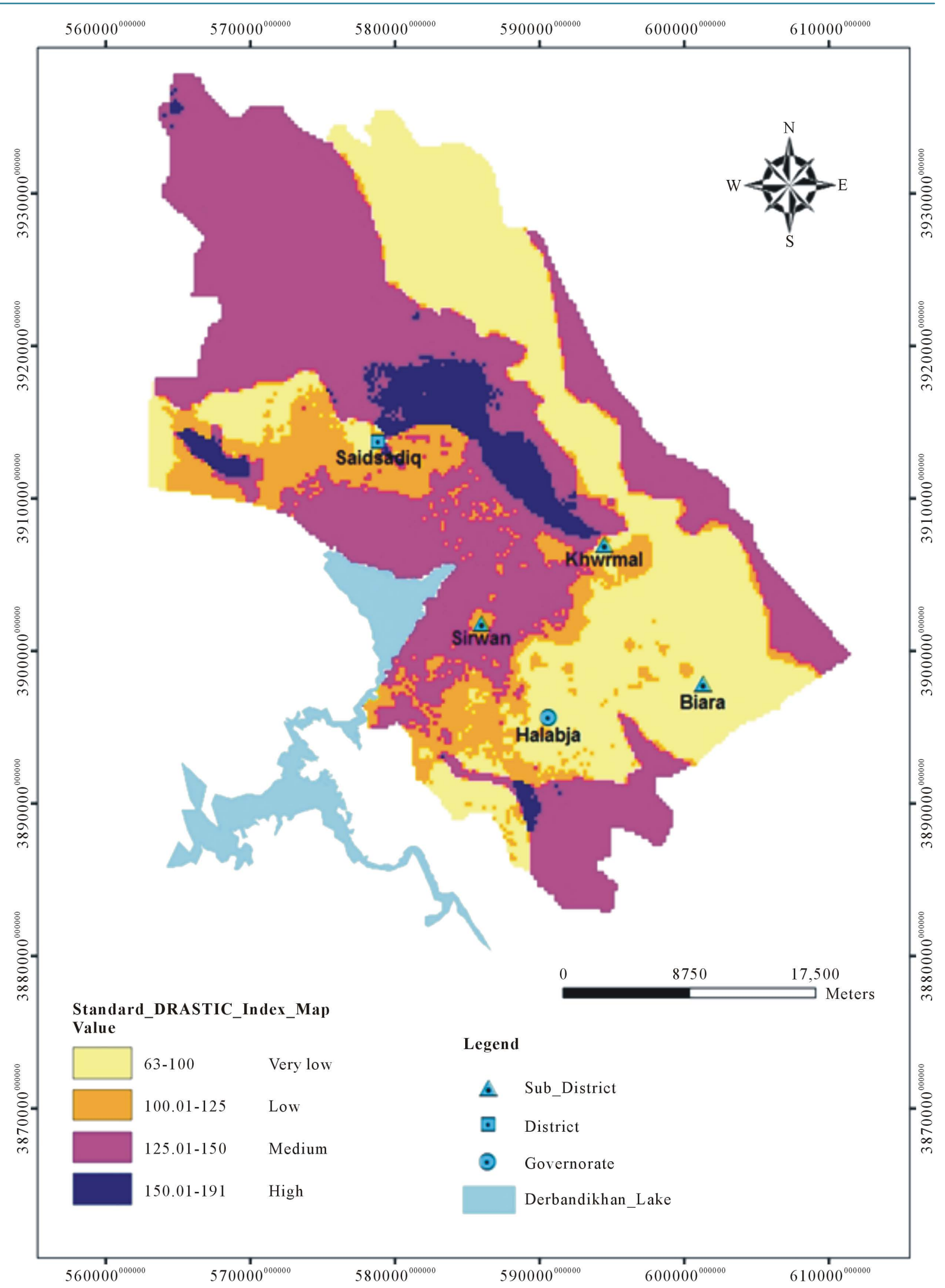

Figure 7. Standard DRASTIC Map for HSB. 


\subsection{Assessment of Lineament Density and Index Maps}

The lineament density map of the study basin is exposed in Figure 8. This map is produced by applying GIS techniques from lineament map extracted from satellite landsat 8 images (ETM+, 2013). The map reveals that HSB divided in to six classes of lineament density distribution as explained on Table 5 with percent and the area of land covering of each.

Figure 8 illustrate the Lineament density map of HSB, it can be noted that Class-VII which is characterized by low density of lineament distribution covered most of studied basin land with an area of (1165.7) $\mathrm{km}^{2}$ or (91.2\%) of total studied area. In addition, the higher lineament density range is Class-I which is occupy only 1.5 $\mathrm{Km}^{2}$ or $(0.12 \%)$ of the whole HSB, which is located along the mountain ranges in the northwestern portion of studied basin, coincident with major subsurface structural development along Sirwan Mountain namely developed thrust fault and overturned double plunging anticline as explained on geological map, Figure 2.

The remaining classes of (Class-II, Class-III, Class-V and Class-VI) covering an area of 5.4, 9.2, 23.9, and $72.3 \mathrm{Km}^{2}$ or $(0.42 \%, 0.72 \%, 1.87 \%$ and $5.66 \%)$ of the whole studied area respectively. Furthermore, from the result mentioned above, it can be concluded that HSB considered as relatively low lineament density.

The map of ratings lineament in (Figure 9) illustrates rating value ranging from 1 - 7 (Table 5). Class- 1 was assigned a probability rating of 7 and occupies only $0.12 \%$ of HSB area, because the density range of lineament considered as high intensity. While Class-VII assigned a probability rating of 1 , as they contain low density range which is only (0 - 1.05). Additionally density ranges of classes (Class-II, Class-III, Class-V, Class-VI) were rated as $(5,4,3$ and 2$)$ respectively and occupied $(0.42,0.72,1.87$ and 5.66$)$ of the whole HSB area respectively.

Furthermore, the lineament density rating map as a raster grid was multiplied using map algebra in GIS environment by the weight of the parameters $(\mathrm{Lw}=5)$ to construct Lineament index map as shown in Figure 10. The index value classified into six classes as well $(5,10,15,20,25$ and 35), which occupies the same area as mentioned previously in the lineament rating map explanation.

\subsection{Assessment of Modified DRASTIC Vulnerability Model}

Figure 11 demonstrate modified DRASTIC index map based on lineament index map with ranging of (68 - 196). The range of index values was divided into four classes including very low to high vulnerability classes (Table 6).

Table 5. Lineament density classes rating in HSB.

\begin{tabular}{ccccc}
\hline Class & Range of Lineament Density Distribution & Rating & Area_Km ${ }^{2}$ & Area_\% \\
\hline Class-I & $>2.1-2.4$ & 7 & 1.5 & 0.12 \\
Class-II & $>1.83-2.1$ & 5 & 5.4 & 0.42 \\
Class-III & $>1.57-1.83$ & 4 & 9.2 & 0.72 \\
Class-V & $>1.3-1.57$ & 3 & 23.9 & 7.87 \\
Class-VI & $>1.05-1.3$ & 2 & 72.3 & 5.66 \\
Class-VII & $0-1.05$ & 1 & & 91.2 \\
& & Weight $=5$ & & \\
\hline
\end{tabular}

Table 6. Standard and modified DRASTIC index value at HSB.

\begin{tabular}{cccc}
\hline \multirow{2}{*}{ Vulnerability Class } & \multicolumn{2}{c}{ Standard DRASTIC } & \multicolumn{2}{c}{ Modified DRASTIC } \\
\cline { 2 - 4 } & Index Value & Area (\%) & Index Value \\
\hline Very Low & $63-100$ & 34 & $68-100$ \\
Low & $>100-125$ & 13 & $>100-125$ \\
Moderate & $>125-150$ & 48 & $>125-150$ \\
High & $>150-191$ & 5 & $>150-196$ \\
\hline
\end{tabular}




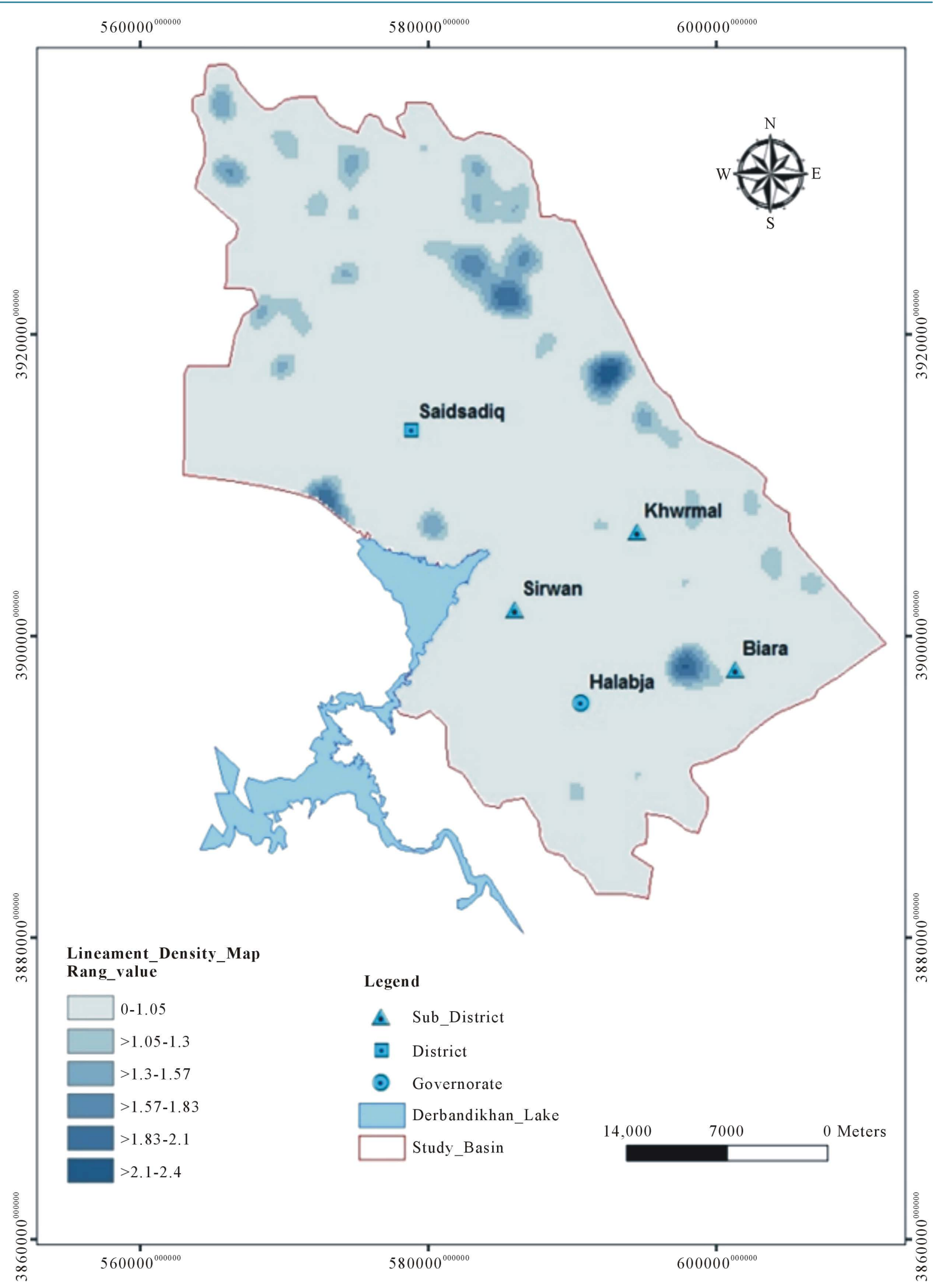

Figure 8. Lineament density map for HSB. 
T. O. Abdullah et al.

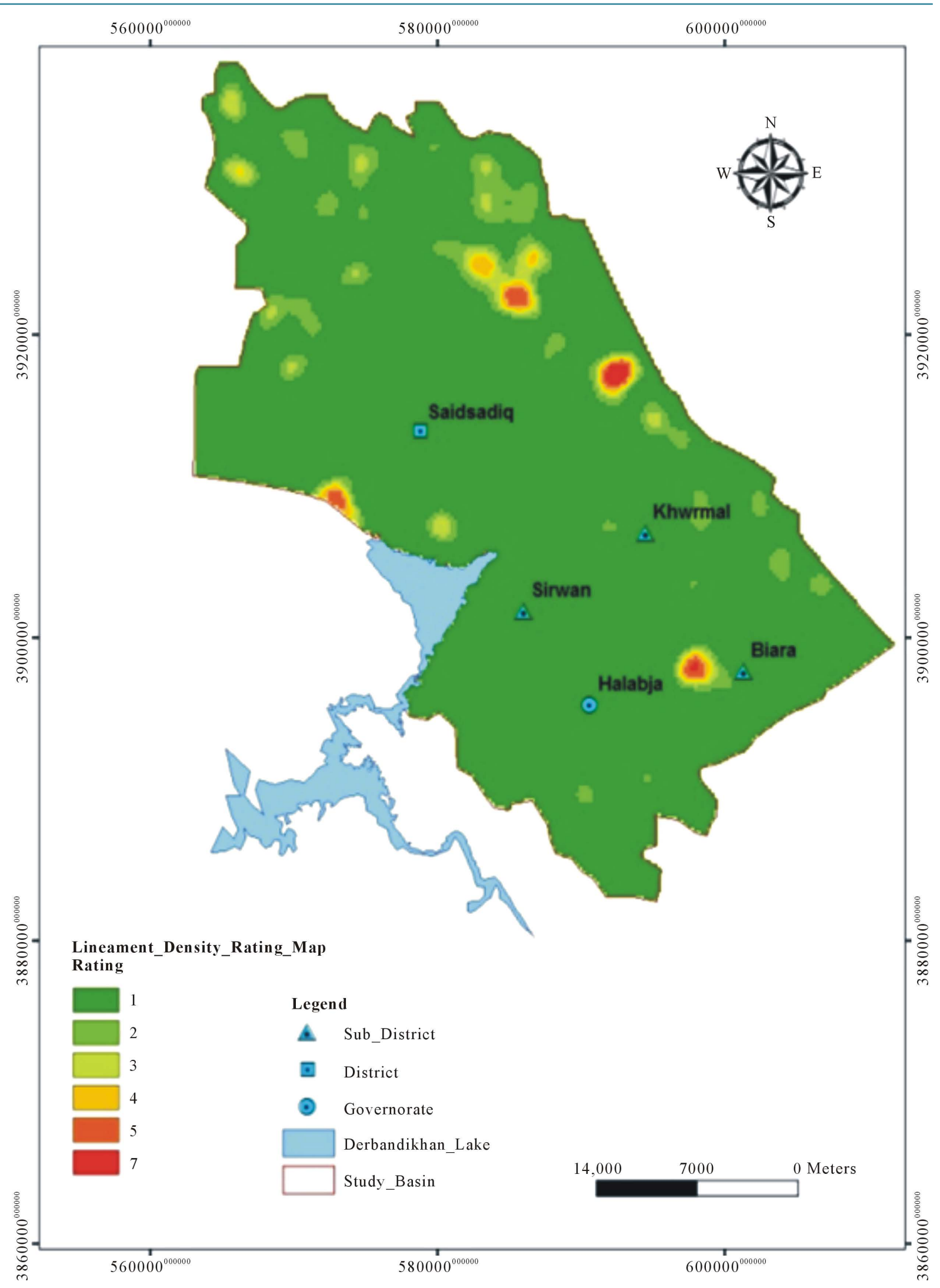

Figure 9. Lineament rating map for HSB. 


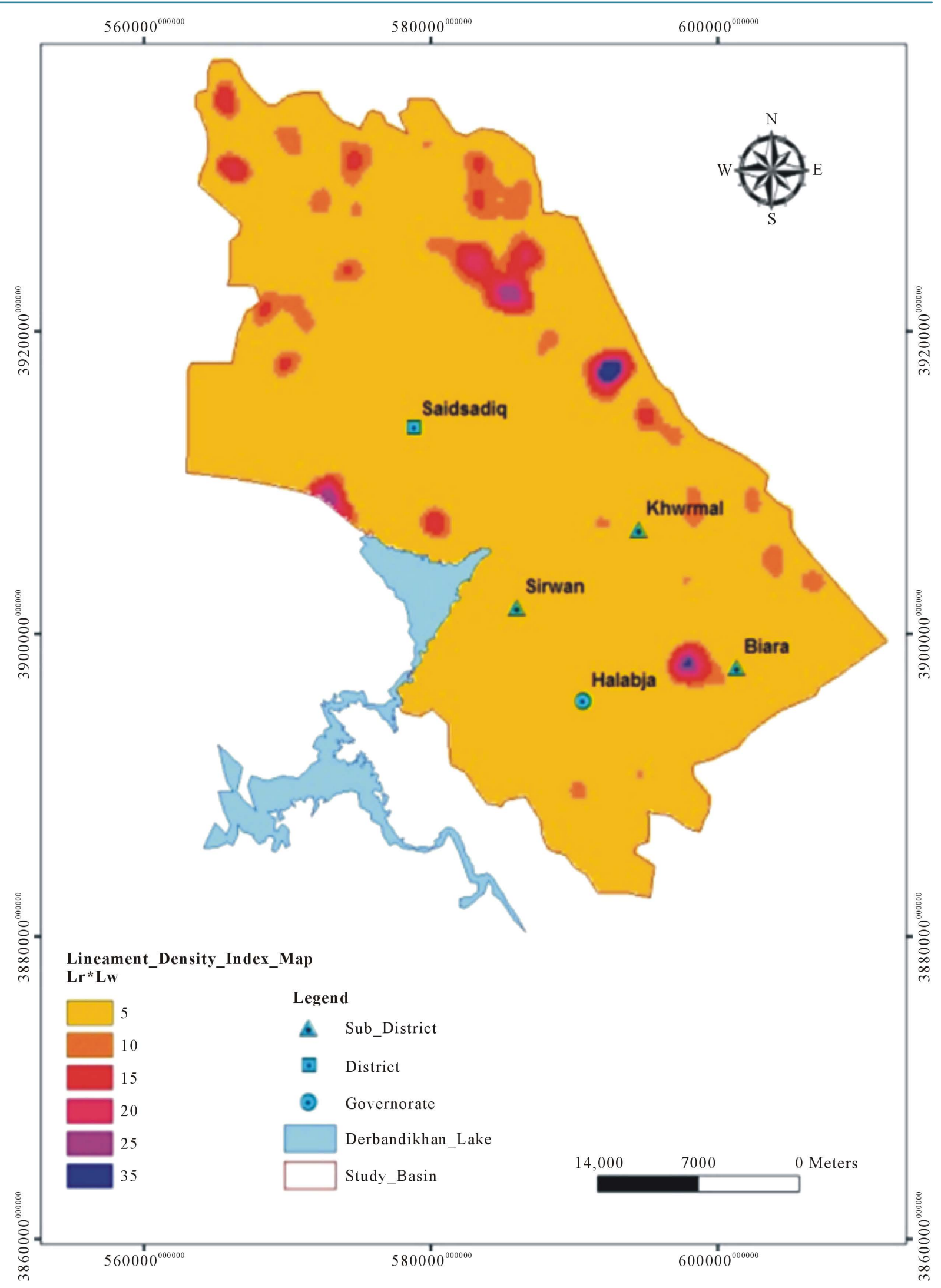

Figure 10. Lineament index map for HSB. 
T. O. Abdullah et al.

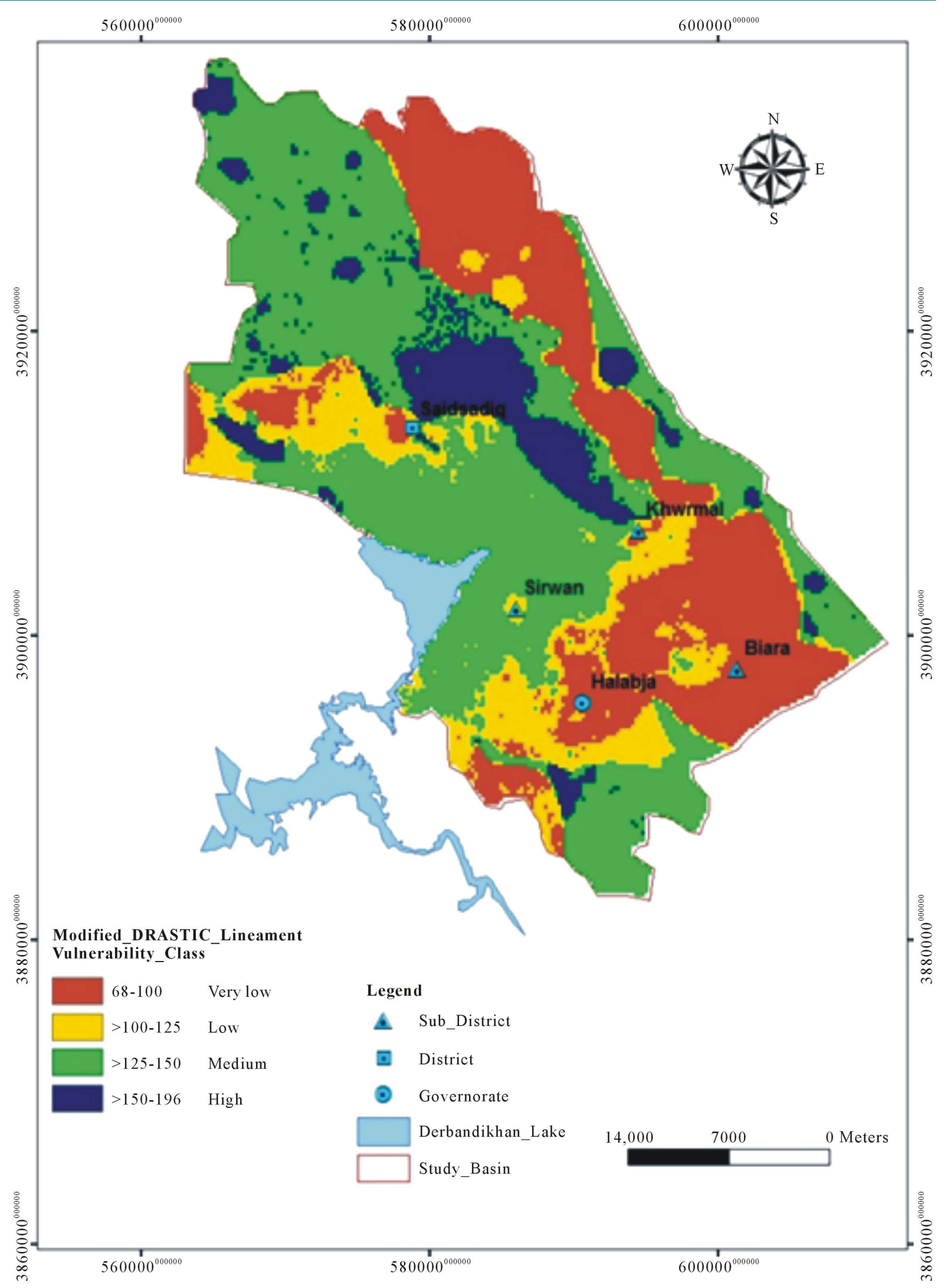

Figure 11. Modified DRASTIC lineament index map for HSB. 
The modified vulnerability map shows that about (47\%) of HSB has moderate vulnerability to contamination with index values ranging between $(125$ - 150). Whilst, very low vulnerability measured was a second effective class in the studied area with (29\%). In addition, (low and high) classes comprise (14\%, and 10\%) respectively. By comparing between Standard DRASTIC and its modification based on lineament density factor, Table 6, clearly it can be noted that there is no significant variation on the index value and the occupy area as well for classes of low and moderate, only the area of high and very low slightly changed. Taken as a whole from this modification, it can be concluded that lineament density is not effect on the vulnerability model at HSB because majority of the studied area characterized by low density range of lineament distribution which is about (91.2\%) of whole HSB area.

\subsection{Validation of Modified Model}

Each vulnerability maps should be validate after constructing in order to estimate the validity of the theoretical sympathetic of current hydrogeological conditions [32]-[34]. Several methods can be apply for the validation of vulnerability assessments [34]; these include hydrographs, chemographs and tracers (natural or artificial). In order to validate both applied models at HSB, nitrate concentration analysis has been selected. Nitrate as a pollution indicator can be used to recognize the groundwater quality evolution in terms of quality changing. In the particular studied case, the nitrate differences between two following seasons (dry and wet) were analyzed from (30) water wells. The samples were collected and analyzed on end of September 2014 for dry season and end of May 2015 for wet season. The selected wells for nitrate concentration measurement located nearly in all vulnerability zones at each models.

In relation to nitrate values for dry season (absence of rainfall for a long period), (Table 7), low nitrate levels were identified with concentration value ranging between zero to just above $10 \mathrm{mg} / \mathrm{l}$. For modified DRASTIC vulnerability classes namely (very low, low, moderate and High), the average of nitrate concentration in dry season were $(<2,0-2,>10$ and $>10) \mathrm{mg} / \mathrm{l}$ respectively (Figure 12(a)). While for wet season the concentration were significantly rose up $(0-20,20-30,>30$ and $>30) \mathrm{mg} / \mathrm{l}$ respectively (Figure 12(b)). This condition refers to several main factors such as rising up the water table in the wet season and vice versa for the dry season. Secondly, the impact of human activity is significant in wet season specifically using chemical contaminants (nitrate) for agriculture purpose. In addition, rainfall plays an important role to transport nitrate based on specific condition of vulnerability properties of ground strata. Consequently, these considerable variations in nitrate concentration from dry to wet seasons verify that there is no effect of lineament density on standard DRASTIC model in HSB. Therefore, the result once more confirmed that the standard model required to be modified with other different parameters such as land use pattern or rate and weight modification.

\section{Conclusions}

To assess the prospective vulnerability of groundwater pollution in the HSB standard DRASTIC index model applied in GIS environment. Although the DRASTIC method regularly affords acceptable results in the assessment of intrinsic vulnerability of groundwater to pollution but it might be difficult to consider the result as an accurate risk assessment of the groundwater. Therefore, lineament density distribution as an additional parameter applied to modify it. Landsat o Thematic Mapper (TM) had been used to prepare Lineament map. Images consist of nine spectral bands with cell size $(30 \times 30 \mathrm{~m})$, the Operational Land Imager (OLI) spectral band in gray scale was used with PCI Geometrica technique. The lineament density map constructed from lineament

\begin{tabular}{|c|c|c|c|c|c|}
\hline \multirow{2}{*}{$\begin{array}{c}\text { Standard DRASTIC } \\
\text { Vulnerability } \\
\text { Category }\end{array}$} & \multicolumn{2}{|c|}{ Nitrate Concentration (mg/l) } & \multirow{2}{*}{$\begin{array}{l}\text { Modified DRASTIC } \\
\text { Vulnerability } \\
\text { Category }\end{array}$} & \multicolumn{2}{|c|}{ Nitrate Concentration (mg/l) } \\
\hline & Dry Season & Wet Season & & Dry Season & Wet Season \\
\hline V. Low & $<2$ & $0-20$ & V.Low & $0-2$ & $20-30$ \\
\hline Low & $0-2$ & $20-30$ & Low & $>10$ & $>20$ \\
\hline Medium & $>10$ & $>30$ & Moderate & $>10$ & $>30$ \\
\hline High & $>10$ & $>30$ & High & $>10$ & $>30$ \\
\hline
\end{tabular}




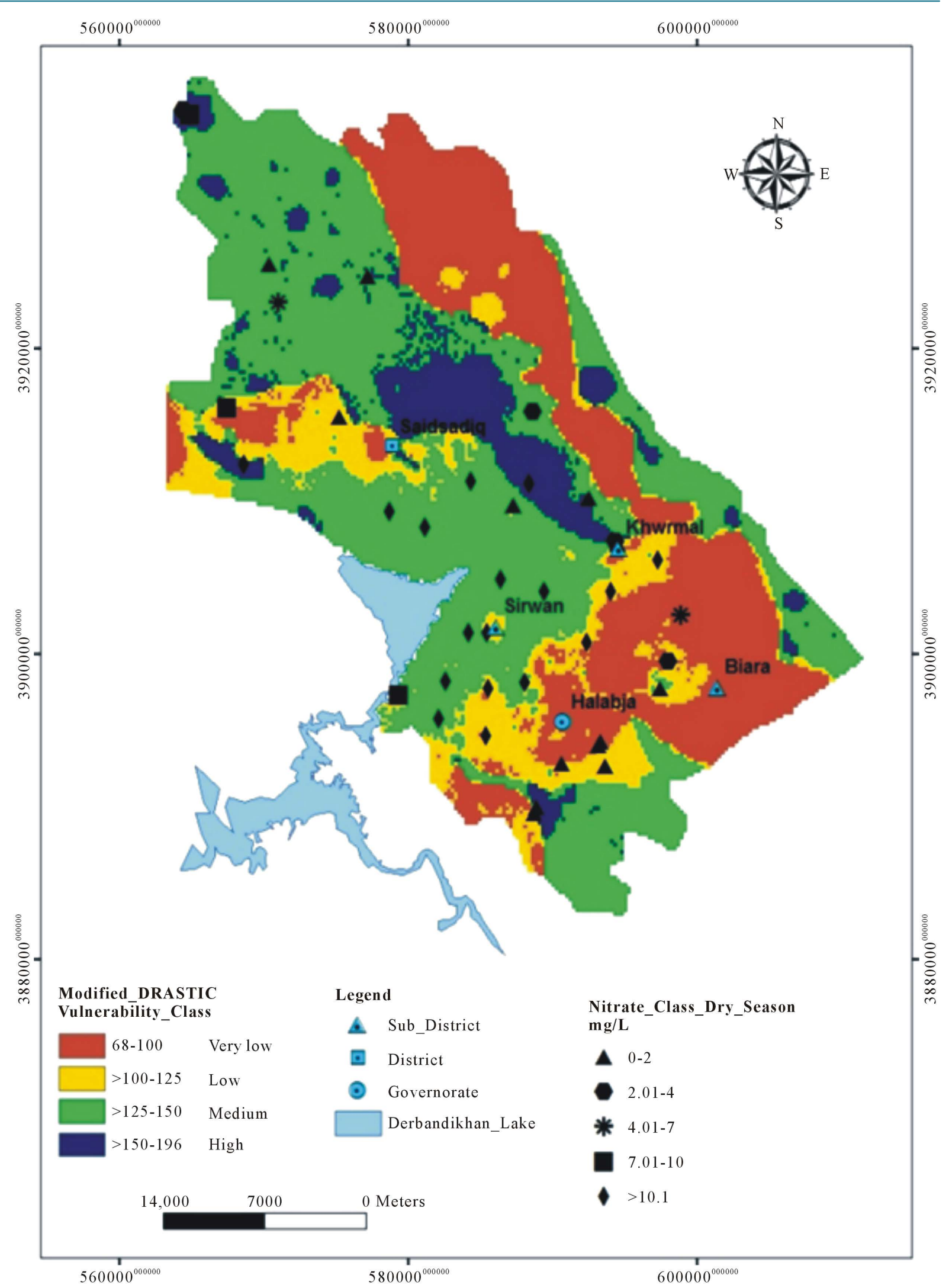

(a) 


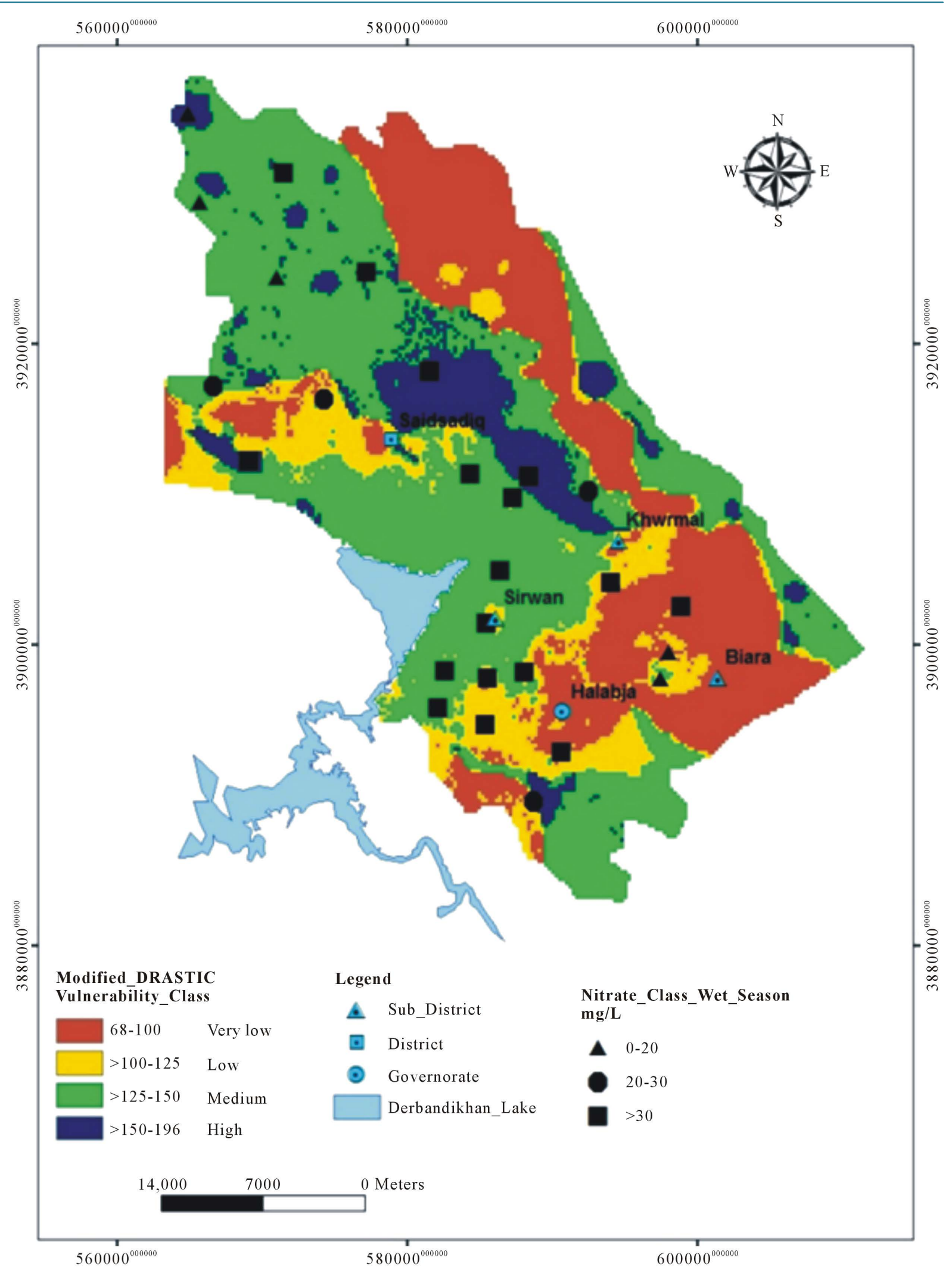

(b)

Figure 12. Modified model with nitrate concentration: (a) dry season; (b) wet season. 


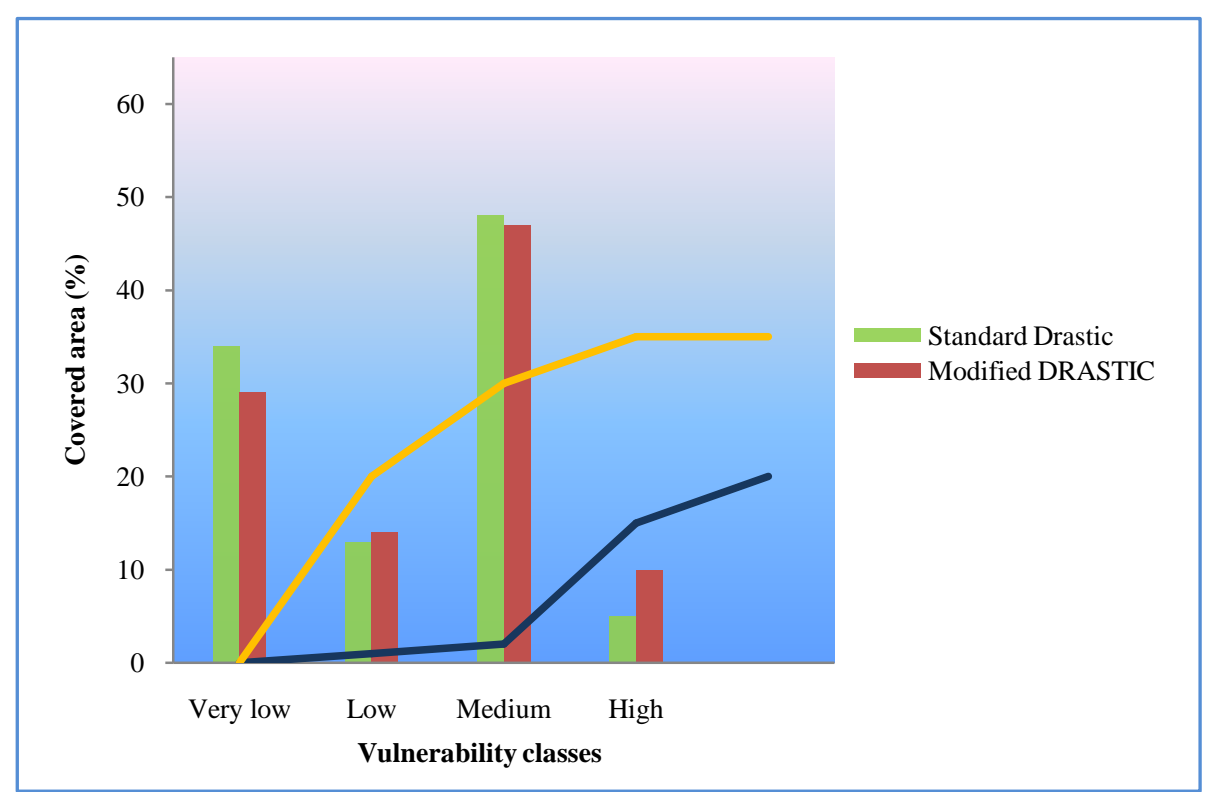

Figure 13. Comparison of both models with nitrate concentration for HSB.

map in GIS environment. The map demonstrates that six classes can be recognized from low to high density. Each class has specific rate and weight value based on its impact environmentally as explained in Table 4. Seven parameter maps were developed in a GIS environment to generate standard models and one parameter ( $\mathrm{Li}$ neament density index map) is added to modify it. The DRASTIC vulnerability index values ranged between (63 and 191), (68 and 196) for standard and modified respectively.

The vulnerability classes are elucidated in the Figure 13. As can be noted, both standard and modified DRASTIC model clarify only four vulnerability classes comprises (very low to high). The moderate vulnerable areas constitute (46.91\%) of the basin for modified results and mostly are located in the central and north west of the HSB. This percent was $48 \%$ before modification which is considered as weak variation. High vulnerability class varied from (5\%) to (10\%) after modification and located in the area of mountain with high lineament density. In addition, a huge variation in the rate of vulnerability has not been seen for the remaining classes. Nitrate as a pollution indicator can be supportive to distinguish the evolution and changes of groundwater quality. In the particular study case, the nitrate differences between two following seasons (dry and wet) were analyzed from (30) water wells to validate the results. The result illustrates considerable variations in nitrate concentration from dry to wet seasons. So it can be concluded that HSB are capable to receiving the contaminant due to its suitability in terms of geological and hydrogeological conditions. As a result, it could be argued that the effect of lineament density is weak on the vulnerability process in HSB. Because standard and modified models provided nearly the same outcome as a result of low lineament density value, on the other hand, nitrate contributed a big variation in its concentration.

\section{References}

[1] Aller, L., Bennett, T., Lehr, J.H., Petty, R.H. and Hackett, G. (1987) DRASTIC: A Standardized System for Evaluating Groundwater Pollution Potential Using Hydrogeologic Setting. USEPA Report 600/2-87/035, Robert S. Kerr Environmental Research Laboratory, Ada, 252 p.

[2] Evans, B.M. and Mayers, W.L. (1990) A GIS-Based Approach to Evaluating Regional Groundwater Pollution Potential with DRASTIC. Journal of Soil and Water Conservation, 45, 242-245.

[3] Fritch, T.G., McKnight, C.L., Yelderman Jr., J.C. and Arnold, J.G. (2000) An Aquifer Vulnerability Assessment of the Paluxy Aquifer, Central Texas, USA, Using GIS and a Modified DRASTIC Approach. Environmental Management, 25, 337-345. http://dx.doi.org/10.1007/s002679910026

[4] Knox, R.C., Sabatini, D.A. and Canter, L.W. (1993) Subsurface Transport and Fate Processes. Lewis Publishers, Boca Raton.

[5] Piscopo, G. (2001) Groundwater Vulnerability Map, Explanatory Notes, Castlereagh Catchment, NSW. Department of 
Land and Water Conservation, Parramatta.

http://www.water.nsw.gov.au/_data/assets/pdf_file/0008/549377/quality_groundwater_castlereagh_map_notes.pdf

[6] Rundquist, D., Peters, A., Liping, D., Rodekohr, D., Ehrman, R. and Murray, G. (1991) State-Wide Groundwater Vulnerability Assessment in Nebraska Using the DRASTIC/GIS Model. Geo Cartography International, 6, 51-58.

[7] Secunda, S., Collin, M. and Melloul, A.J. (1998) Groundwater Vulnerability Assessment Using a Composite Model Combining DRASTIC with Extensive Land Use in Israel's Sharon Region. Journal of Environmental Management, 54, 39-57. http://dx.doi.org/10.1006/jema.1998.0221

[8] Plymale, C.L. and Angle, M.P. (2002) Groundwater Pollution Potential of Fulton County, Ohio. Groundwater Pollution Potential, Report 45. Ohio Department of Natural Resources Division of Water, Water Resources Section, Columbus.

[9] Al-Rawabdeh, A.M., Al-Ansari, N.A., Al-Taani, A.A., Al-Khateeb, F.L. and Knutsson, S. (2014) Modeling the Risk of Groundwater Contamination Using Modified DRASTIC and GIS in Amman-Zerqa Basin, Jordan. Open Engineering, 4, 264-280. http://dx.doi.org/10.2478/s13531-013-0163-0

[10] Lattman, H. and Parizek, R. (1964) Relationship between Fracture Traces and the Occurrence of Ground Water in Carbonate Rocks. Journal of Hydrology, 2, 73-91. http://dx.doi.org/10.1016/0022-1694(64)90019-8

[11] Fernandes, D. and Rudolph, A. (2001) The Influence of Cenozoic Tectonics on the Groundwater Production Capacity of Fractured Zones: A Case Study in Sao Paulo, Brazil. Hydrogeology Journal, 9, 151-167. http://dx.doi.org/10.1007/s100400000103

[12] MOCT (Ministry of Construction and Transportation) and KOWACO (Korea Water Resources Corporation) (1998) The Handbook of Drawing and Management of Hydrogeological Map. MOCT, Sejong City, 456.

[13] Ali, S.S. (2007) Geology and Hydrogeology of Sharazoor-Piramagroon Basin in Sulaimani Area, Northeastern Iraq. Unpublished PhD Thesis, Faculty of Mining and Geology, University of Belgrade, Belgrade, 317 p.

[14] Huang, T.M., Pang, Z.H. and Edmunds, W.M. (2012) Soil Profile Evolution Following Land-Use Change: Implications for Groundwater Quantity and Quality. Hydrological Processes, 27, 1238-1252. http://dx.doi.org/10.1002/hyp.9302

[15] Buday, T. (1980) Stratigraphy. In: Kassab, I.I. and Abbas, M.J., Eds., The Regional Geology of Iraq, Vol. 1, Mining Investigation Publication, Baghdad, 445 p.

[16] Buday, T. and Jassim, S. (1987) Tectonics, Magmatism, and Metamorphism. In: Kassab, I.I. and Abbas, M.J., Eds., The Regional Geology of Iraq, Mining Investigation Publication, Baghdad, 445 p.

[17] Jassim, S.Z. and Goff, J.C. (Eds.) (2006) Geology of Iraq. D.G. Geo Survey, Mining Investigation Publication, Baghdad, $341 \mathrm{p}$.

[18] Bellen, R.C., Dunnington, H.V., Wetzel, R. and Morton, D. (1959) Lexique Stratigraphique International Asie, Iraq. Vol. 3C, 10a, 333 p.

[19] Baziany, M.M.Q. (2006) Stratigraphy and Sedimentology of Former Qulqula Conglomerate Formation, Kurdistan Region, NE-Iraq. Msc Thesis, Sulaimani University, Sulaymaniyah, 98 p.

[20] Baziany, M.M.Q. and Karim, K.H. (2007) A New Concept for the Origin of Accumulated Conglomerates, Previously Known as Qulqula Conglomerate Formation at Avroman-Halabja Area, NE-Iraq. Iraqi Bulletin of Geology and Mining, 3, 33-41.

[21] FAO Representation in Iraq (2001) Reconnaissance Soil Map of the Three Northern. Governorates, Iraq. Map Scale $=1: 1000,000$. Erbil Sub-Office.

[22] Stevanovic, Z. and Markovic, M. (2004) Hydrogeology of Northern Iraq: Climate, Hydrology, Geomorphology and Geology. Vol. 1, 2nd Edition, FAO, Rome.

[23] Groundwater Directorate in Sulaimaniyah (2014) Archive Department.

[24] Mehta, V.K., Walter, M.T. and DeGloria, D.S. (2006) A Simple Water Balance Model. Cornell University, Technical Report No.5, 9 p.

[25] Allen, R.G., Pereira, L.S., Raes, D. and Smith, M. (2006) Crop Evapotranspiration: Guidelines for Computing Crop Water Requirements. FAO Irrigation and Drainage Paper No. 56, 23.

[26] Lee, S. (2003) Evaluation of Waste Disposal Site Using the DRASTIC System in Southern Korea. Environmental Geology, 44, 654-664. http://dx.doi.org/10.1007/s00254-003-0803-4

[27] Berding, F. (2003) Agro-Ecological Zoning of the Three Northern Governorates of Iraq, FAO Agricultural Rehabilitation Programme. Plant Production SS, Erbil.

[28] Hernandez, L.R., Bravo, J.A. and Mejuo, M.F. (2004) Map of Vulnerability to Groundwater Contamination. Excelentisima Diputacion Provincial de Alicante, Espana. A-1029-2004. 
[29] Hamamin, D.F. (2011) Hydrogeological Assessment and Groundwater Vulnerability Map of Basara Basin, Sulaimani Governorate, Iraq, Kurdistan Region. Unpublished PhD Thesis, College of Science, University of Sulaimani, Sulaymaniyah, $174 \mathrm{p}$.

[30] PCI Geomatica (2001) PCI Geomatica User’s Guide Version 9.1. Richmond Hill.

[31] Al-Rawabdeh, A.M., Al-Ansari, N.A., Al-Taani, A.A. and Knutsson, S. (2013) A GIS-Based DRASTIC Model for Assessing Aquifer Vulnerability in Amman-Zerqa Groundwater Basin, Jordan. Engineering, 5, 490-504. http://dx.doi.org/10.4236/eng.2013.55059

[32] Brouyère, S., Jeannin, P.Y., Dassargues, A., Goldscheider, N., Popescu, C., Sauter, M., Vadillo, I. and Zwahlen, F. (2001) Evaluation and Validation of Vulnerability Concepts Using a Physically Based Approach. 7th Conference on Limestone Hydrology and Fissured Media, Besançon, 20-22 September 2001, 67-72.

[33] Perrin, J., Pochon, A., Jeannin, P.Y. and Zwahlen, F. (2004) Vulnerability Assessment in Karstic Areas: Validation by Field Experiments. Environmental Geology, 46, 237-245. http://dx.doi.org/10.1007/s00254-004-0986-3

[34] Zwahlen, F. (Ed.) (2004) Vulnerability and Risk Mapping for the Protection of Carbonate (Karst) Aquifers, Final Report (COST Action 620). European Commission, Brussels. 